\title{
Research on the Causes and Countermeasures of the Development Disadvantages of China's Overseas Consumption Education Service Trade
}

\author{
HongxingLIU ${ }^{1}$, Mengxin $\mathrm{CAO}^{2, a}$ \\ 1 Jiangxi Normal University Science and Technology College, China \\ 2Jiangxi Normal University Education College, China \\ a jxsdjh@vip.sina.com
}

Key words: Education service trade, Overseas consumption, Development strategy

\begin{abstract}
In the current era, the trade in education services in various countries has developed rapidly, and the trade in overseas consumer education services is the most important mode of trade in educational services. However, China's overseas consumer education service trade is in a disadvantaged position compared with developed countries. This paper analyzes the current situation of China's overseas consumer education service trade, analyzes the causes of its disadvantages, and finally gives countermeasures and suggestions to promote the development of China's overseas consumer education service trade.
\end{abstract}

\section{Introduction}

In recent years, the Chinese government has attached great importance to the development of overseas consumer education services and has introduced a series of policies to encourage international students to enroll students. Universities and colleges have also begun to pay attention to the development of international student education services, and the number of international students coming to China has increased year by year. However, the source structure of Chinese students is relatively simple, and the source is mainly distributed in Asia. Geopolitical factors and cultural similarities are important factors influencing the development of consumer services abroad.The students from China are mainly concentrated in neighboring countries or regions in China. They have certain similarities in culture and language. Students from these countries have certain advantages in studying in China, and the market prospect is good. However, the excessive concentration of the student source structure is not conducive to China's evasion of the export risk of overseas consumer education service trade. Once the number of students coming to China from these countries has plummeted, it will have an adverse impact on the development of China's overseas consumer education service trade. In contrast, developed countries, with their strong economic strength and international influence, attract international students from all over the world and take the lead in the international market.

\section{The causes of the development disadvantages of China's overseas consumption education service trade}

\subsection{Lack of high-level faculty}

The faculty is the most important productive resource in colleges and universities, and it is the main force for the university to realize the talent training strategy. From the perspective of teacher structure, there are irrational phenomena in the academic structure, age structure and disciplinary structure of college teachers in China. The teacher resources are inclined to the key universities in China, and the resource allocation of teachers is unreasonable. There are fewer high-level teachers from abroad, which is not conducive to academic international exchanges, nor to the construction of disciplines and the construction of teaching features in universities, and it is difficult to attract international 
students. Secondly, from the perspective of teachers, the vast majority of college teachers in developed countries have doctoral degrees, and the faculty has a strong lineup. Most of the teachers in famous universities in the United States have doctoral degrees from prestigious universities. Therefore, China's overseas consumer education services lack competitiveness in the international market.

\subsection{Lack of education quality supervision system}

The competition in the international education market is ultimately the competition for the quality of education. Both the government and the university must recognize that the guarantee of quality of education is of great significance to the international market. Most developed countries have set up quality supervision systems for higher education, such as Australia. In order to improve the competitiveness of higher education in the international market, a quality assessment system for higher education has been established, and a non-governmental third-party institution has been established. Guarantee Department. It is responsible for assessing and supervising Australian higher education institutions and submitting educational quality assessment reports to the Australian and Australian universities for internal and external evaluation procedures. This reflects the country's mature quality assurance system for higher education, which can guide and help universities at different levels to define their educational orientation and provide suggestions for improvement. However, China still lacks a relatively complete education quality certification system and lacks a comprehensive evaluation report on higher education. Foreign students lack channels and information to understand Chinese higher education, which weakens the willingness of international students to study in China.

\subsection{Lack of standardized market management}

China has not yet established a market for higher education overseas consumer service trade. The existing domestic study intermediary market is still not standardized. Some overseas study agencies do not pay attention to the long-term development of business, and their short-sighted has occurred from time to time. In addition, the quality of the employees in the intermediary agencies is not high, most of them have not been professionally trained, and the employment permit system has not yet been established. In the intermediary market for study abroad, there are malformations in development, and there are many intermediaries for studying abroad, and there are few intermediaries that introduce foreign students and recommend excellent universities and dominant disciplines in China. Second, the overseas consumer education service trade management system is not perfect and lacks policy and data support. China has not yet issued a general law on trade in education services. The incompatibility of such policies has led to opaque policies on the development of education services trade in China, which has hindered the healthy development of the import and export of education services trade. Moreover, it lacks systematic research on the development of foreign education service trade, is not familiar with the practices of foreign educational institutions, and is not able to learn from it. It does not clarify the needs of student consumers in various countries and does not have the enthusiasm to expand the international market. China has not yet developed a sound and comprehensive overseas consumer education service trade market.

\section{Promotion strategies for the development of overseas consumer education service trade in China}

\subsection{Build a personalized faculty}

Yiqi Mei, a modern educator and president of Tsinghua University, once put forward the famous master theory: "The so-called university people, not only have the building, but also the master."The faculty is the most important productive resource in colleges and universities, and it is the main force for the university to realize the talent training strategy. The development of a country's higher education services depends largely on the level of education and teaching of teachers. The quality of 
teachers' teaching determines the quality of education in colleges and universities. In the face of increasingly fierce international competition, Chinese universities must implement a talent strategy and actively train quality teachers.

First of all, it is necessary to improve the entry threshold for college teachers, and strictly require the qualification certification and level certification of the applicants. Secondly, it is necessary to formulate a strategic plan for the development of the teaching staff, and train the teaching staff in batches and in a timely manner to promote the growth of their business capabilities in a sustained and stable manner. Third, it is necessary to rationally allocate teacher resources, improve the overall quality of the teacher group, and promote the rationalization of the structure of the teaching staff.

\subsection{Create a high level of education quality}

To promote the development of overseas consumer service trade in higher education, it is necessary to optimize the management system, rationally allocate resources, and improve the level and efficiency of running schools. For the education administrative department, it is necessary to strengthen the unified management of the overseas consumer education service trade market, and establish and improve the quality assessment and monitoring system for foreign students. Establish an independent, professional third-party higher education quality supervision agency and social intermediary agency. Responsible for supervising the quality of teaching in colleges and universities, providing their own suggestions and countermeasures for the international development of colleges and universities, and publishing educational quality testing reports to the public, providing reference materials for students at home and abroad to choose the school that suits them. For colleges and universities, colleges and universities should reform the unreasonable curriculum system and create an international student curriculum system that is in line with international courses. Improve teaching methods, update teaching content, prepare excellent textbooks for international students; improve the logistics management system for international students, provide them with a good accommodation and environment, and do a good job in logistics services. Improve the medical insurance system for international students, and provide convenient conditions for foreign students to see a doctor. We will improve the work-study and internship system for international students, and provide opportunities for international students to work part-time, internships, and employment in China.

\subsection{Establish awareness of education industrialization}

It is unrealistic to raise the level of running schools in all universities at present. The government should focus on building institutions of higher learning that are quite influential in the world like Peking University and Tsinghua University, and build them into world-class universities with international advanced levels. . Through their participation in the practice of international competition, establish Chinese brands and vigorously develop the international market for higher education.

Colleges and universities should further strive for autonomy in running schools, establish awareness of industrialization, and operate higher education as an industry, so that universities can participate in international competition as market players. For example, on March 26, 2018, Peking University's 120th Anniversary Celebration and Peking University UK Campus Launching Ceremony was held in Oxford. This is the first overseas campus of Peking University. It is also the first time that a higher education institution in China has gone abroad to operate a branch school in the form of sole proprietorship and independent management. It is a milestone in the history of Chinese higher education. China should encourage universities to go global, face the international market with confidence and a strong attitude, participate in international competition, show the latest developments of Chinese colleges and universities in the world, and expand the influence of Chinese university brands in the international market as much as possible. Publicity, leaving a Chinese impression to foreign students. 


\section{Conclusion}

The development of overseas consumer education service trade can not only bring greater economic income, but also promote the export and dissemination of Chinese culture, which is conducive to China's social modernization and the development of Chinese culture. However, the education service trade market has an uneven situation. China has a significant deficit and disadvantage in the overseas consumption of higher education service trade. It is mainly due to the lack of high-level teacher strength, education quality supervision system, government policy support, and standardized market management. Therefore, it is necessary to promote the development of China's overseas consumer education service trade by constructing a personalized faculty, creating a high level of education quality.

\section{References}

[1] Jie Shi, Research on the International Competitiveness of China's Higher Education Service Trade,2012,pp.52-55

[2] XH Si. Jia Hou, An Analysis of the Characteristics of Australian Higher Education Development,J.Higher Education Research, 2012,pp. 102-109

[3] Xiaojia Chen,Comparison Research on International Competitiveness of Higher Educational Service Trade Between China and US,2016

[4] Guojun Zhang,Study on Chinese Consumption abroad of Education Service Trade,J.China Higher Education Research,2014(1)

[5] CM Zhao,Research on the Development of International Education Service Trade and the Transnational Flow of Talents,Economic science Press,Beijing,2015,pp.177-183.

[6] HM Li, WJ Chen, The Development Trend of Global Higher Education Service Trade and Its Enlightenment to China,J.2014(3),pp.63-66 